\title{
Sentience and welfare for animals used in experiments*
}

\author{
Marita Giménez-Candela \\ Founder and Chief Editor \\ Orcid:0000-002-0755-5928
}

Received: October 2018

Accepted: October 2018

Recommended citation. GIMÉNEZ-CANDELA M., Sentience and welfare for animals used in experiments, dA. Derecho Animal (Forum of Animal Law Studies) 9/4 (2018) https://doi.org/10.5565/rev/da.385

* This piece is a part of the MINECO DER2015-69314-P investigation Project «Estatuto jurídico de los animales: origen, desarrollo y políticas» (Legal status of animals: origin, development and policies) (2015-2019), the author of which is the lead investigator, along with other national and international investigators.

\section{Abstract}

Sentience is the central axis around which the debate for whether animals feel, perceive and experience pain, pleasure, and suffering revolves and, as a consequence, is also the determining factor that enables the evaluation of animal welfare. Evidence for animal sentience as a scientific standard that determines legal regulations is, among other things, the abundance of EU regulation on animal welfare, which has established animal sentience as a regulator for over 40 years. Considering here the connection between sentience, animal welfare and the application of these criteria in the field of regulation relating to animal experimentation - one of the most controversial and contested fields - permits reflection on a particularly relevant question, which is the confluence in the work of veterinarians, bio scientific experts and jurists

Keywords: Sentience, sentient beings, feelings, emotions, animal welfare, animal law, EU, EU animal welfare regulations, animal experimentation, laboratory animals, art. 13 TFEU, veterinarians and jurists.

\section{Resumen - Sentiencia y bienestar en animales de experimentación}

La sentiencia constituye el eje central del debate acerca de si los animales sienten, perciben y experimentan dolor, placer, sufrimiento y, como consecuencia, suele ser también el factor determinante que permite valorar el bienestar animal. Que la sentiencia animal es hoy un estándar científico que determina la normativa jurídica, se revela -entre otros ámbitos-, en la abundante normativa sobre bienestar animal en la UE, que ha establecido la sentiencia de los animales como estándar regulador desde hace más de 40 años. Aquí se plantea la conexión entre sentiencia, bienestar animal y la aplicación de estos criterios en el campo de la normativa relativa a la experimentación con animales que, por constituir uno de los campos más controvertidos y cuestionados, permite 
plantear una cuestión especialmente relevante, como es la confluencia del trabajo entre veterinarios, expertos en biociencias y juristas.

Palabras clave: Sentiencia, seres sintientes, sentimientos, emociones, bienestar animal, derecho animal, UE, normativa UE sobre bienestar animal, experimentación animal, animales de laboratorio, art. 13 TFUE, veterinarios y juristas.

\section{SUMMARY}

I. Sentience: a scientific standard for legal regulation

II. Animal experimentation in the debate on welfare

III. Veterinarians and Jurists: a common aspiration

\section{SENTIENCE: A SCIENTIFIC STANDARD FOR LEGAL REGULATION}

One of the great challenges undertaken by the EU in terms of animal protection has been to tie Animal Welfare regulation to the affirmation of animal sentience. Since the first regulations on Animal Welfare, the EU has effectively held sentience as the standard for declaring animals to be "sentient beings" and, as a result of this, for applying the corresponding public policies that, over the course of 40 years, have turned the EU into a supranational ambit endowed with a legislative corpus, which constitutes a model that has inspired many countries.

Sentience - the capacity to feel, perceive and experience - is fundamental in the debate on the welfare of animals, as it sets out the central question of whether animals suffer during life and during death, and the repercussions that result from this, as much in the ethical ambit, regarding the treatment that we afford them, as in the legal rules that dictate such treatment. In other words, if sentience is the fundamental inspiration for all regulations adopted by the Member States of the EU, as well as by many other countries, the debate will revolve around how this scientific criterion has been applied to legal regulation.

Animal sentience is generally understood as an objective criterion, but open to study and modification; advances in the biosciences are inconclusive, but continue to provide new information that allows:

a) a clearer understanding of what sentience is, and its relation with animal welfare,

b) a greater array of animals with sentience, where it can be proved that each can experience pain, suffering, and positive emotions and sentiments,

c) the determination of our responsibility regarding how we meet our obligations towards the animals with which we interact; essentially, how we give legal form to the protection of the interests of animals, while also offering protection for human interests.

Sentience implies a certain level of awareness, but, awareness of oneself, being, as it is, a complex issue, has also been revised in light of the results that the most up to date science has been able to achieve. In this sense, one understands the relevance of the Cambridge Declaration ${ }^{1}$ (made public in 2012) for broadening scientific discourse on

\footnotetext{
${ }^{1}$ The Cambridge Declaration on Consciousness, http://www.jamiegriffiths.com/the-cambridge-
} declaration-of-consciousness/ 
animal sentience that, in a special case of scientific results permeating the social realm, has spread to improve the public knowledge on the similarity between animals and the human being specifically in terms of sentience.

Science affirms that fully developed vertebrate animals and some invertebrates are sentient, but that neither humans nor non-humans are sentient in the primary stages of their development, or whether they even feel cerebral damage. In a similar sense, when we refer to feelings, I would like to specify that experiencing feelings constitutes a valiant adaptation mechanism, afforded by nature to both humans and nonhumans, and constitutes an important aspect of welfare. In this sense, it is worth mentioning that the term welfare refers to all animals, and not only to sentient animals.

Animal sentience is a concept that, as it has been said, in addition to having experienced a notable development in the scientific realm - which has opened the way for genuine debates - has also sparked a particular interest and development in the social and public realm. In they way that it constitutes one of the greater worries that bothers the individual these days, society notably exteriorises its desire that the living conditions of animals - what is scientifically known as welfare - corresponds to their capacity to feel. This permeation of sentience in the public realm has taken the form of public demonstrations (collecting signatures, the rejection of abuse, social media campaigns) that have propagated the creation important changes in the legal system; the legislator has not even been able to resist meeting the social demands - driven by formal requests - for changes in legislation, revolving around the improvement of the condition of animals and its adaptation of the category of sentient beings. This has broken a long tradition of silence, negation and ignorance on the sincere consideration of animals and their ethical and moral value and, aside from this, is an awareness that is constantly growing and that demands the adaptation of legislation on animals to new scientific parameters.

I am referring in particular to the process we call the "De-objectification" of animals, which reveals itself in the changes experienced by the legal status of animals since the 80 s in central European countries, adopting a negative form: "animals are not things" and, in the first decade of the new millennium, adopting, more coherently with scientific advances, an affirmative form: "they are sentient beings", or the linguistic turn: "they are living beings endowed with sensibility", which has transformed the category of ownership of animals in the primary European Civil Codes and also begins to show itself, in the form of changes or proposals for change, in the Latin-American Civil Codes.

Therefore, in the legal realm, animal sentience has up to now projected itself into the following normative and doctrinal fields:

- In EU legislation on animal welfare, on certain species and groups of animals classified by an economic criterion of production animals, experimentation animals, animals for fur, animals in shows, companion animals, the transport of animals

- In the Civil Codes, in terms of property, in the rules on marital separation or divorce and in the obligations in terms of seizure and confiscation

- In the Constitutions, adopting the form of protecting the dignity intrinsic to animals, or a better integration of animals in the area of environmental protection

- In the court rulings of the European union and in the rulings of courts in certain Member States of the EU and of other countries outside the EU.

The exhibited criteria, however, remain in conflict with the preferential commercial and unilateral focus adopted by the EU and its legislative and judicial organs up until now, since, despite having firmly and indubitably having recognised that animals are "sentient 
beings", continues to treat them, very worryingly, as mere "products", or "goods" within the economic framework. The terminological and legal incoherencies in the treatment of animals by current regulations must be resolved, beyond the broader debate of whether sentient beings can be objects of ownership or whether ownership entails rights that obstruct a wider reflection; this inevitably drives the central question of whether animals are and should be subjects or objects of protection. The EU and the Member States must answer this question, in order to adequately respond to the worries of citizens on the situation of animals, not only in the EU, but across the world, and in this way address a legal vacuum that becomes greater by the day, and at the same time affords more protection to animals; however, it does not address the situation, because the premises on which it is based are inadequate and require revision.

Lastly, if animal sentience and welfare form a tandem that is inseparable from the current legal treatment of animals (in the EU and in its neighbouring countries), it is worth reflecting on the use of animals for scientific purposes, in as much the European regulation as in its specific application in national legislation, for dealing with one of the most controversial cases for testing the efficacy of this tandem, and also because investigation is one of the aspects to which the TFEU programmatically refers when establishing sentience as a valid standard for measuring the level of animal welfare.

\section{ANIMAL EXPERIMENTATION: WELFARE AND SENTIENCE}

The general principles of the Treaty on the Functioning of the European Union $(\mathrm{TFEU})^{2}$ includes in a restrictive sense animal welfare as a general principle of Community Law, in as much as it is mentioned in Title II of the TFEU (Provisions having general application). Explicitly, art. 13 states that:

"In formulating and implementing the Union's agriculture, fisheries, transport,
internal market, research and technological development and space policies, the
Union and the Member States shall, since animals are sentient beings, pay full
regard to the welfare requirements of animals, while respecting the legislative or
administrative provisions and customs of the EU countries relating in particular to
religious rites, cultural traditions and regional heritage".

In fact, the second preliminary clause of Directive 2010/63/EU of the European Parliament and of the Council of 22 September 2010 on the protection of animals used for scientific purposes, ${ }^{3}$ reiterates, "animal welfare is a value of the Union that is enshrined in Article 13 of the Treaty on the Functioning of the European Union". It elevates animal welfare to a "value of the Union", which is not only recognised, but "enshrined" by the TFEU. What it is saying is that it is inalienable for the Member States and that their domestic regulation must keep animal welfare in mind.

At the same time, the third preliminary clause clarifies that "on 23 March 1998 the Council adopted Decision 1999/575/EC concerning the conclusion by the Community of the European Convention for the protection of vertebrate animals used for experimental and other scientific purposes". ${ }^{4}$ By integrating this as part of the Convention, the EU has

\footnotetext{
${ }^{2}$ European Union, Consolidated version of the Treaty on the Functioning of the European Union, 13 December 2017, 2008/C115/01, http://www.refworld.org/docid/4b17a07e2.html (accessed October 2018).

${ }^{3}$ Directive 2010/63/EU of the European Parliament and of the Council of 22 September 2010 on the protection of animals used for scientific purposes, https://eur-lex.europa.eu/legalcontent/EN/TXT/?uri=celex:32010L0063 (accessed October 2018).

${ }^{4} 1999 / 575 / E C$ : Council Decision of 23 March 1998 concerning the conclusion by the Community of the European Convention for the protection of vertebrate animals used for experimental and other scientific purposes, https:/eur-lex.europa.eu/legal-content/ES/TXT/?uri=CELEX:31999D0575
} 
recognised the international importance of the protection and welfare of animals used for scientific purposes. As such, this principle of protection positions itself in a general hierarchy, for which it refers to community policies, included the interior market (article 26 and following), and, in particular, the free movement of goods (article 28 and following), the approximation or harmonisation of national legislation (article 114), as well as investigation and development (article 179 and following).

In principal, this means that the aforementioned sectorial policies, and specifically those relating to animal experimentation, must clearly bear in mind the welfare needs of animals as sentient beings. In this respect, it is worth pointing out that, according to prevailing Jurisprudence of the Court of Justice of the European Union, the general principles of Community Law (including the aspects set out in article 13) prevail as superprinciples, not only from the community sources and the law deriving from them (regulations, directives, decisions), but also of the derived (or that can be derived) regulations and principles of subsequent rules of the TFEU and, in particular, of the regulations relating to the provisions for approximating and harmonising national legislation contained in article 114 .

In fact, with the passing of the $\mathrm{TEU}^{5}$ and the TFEU, the exception to the principle of the single market and of free competition has been permanently abandoned in favour of a compendium of general rules that highlight the gradual transition of the European Union from a predominantly economic community to a truly political and social Union. This means that the general principles, like those that appear in article 13, are not mere programmatic principles, but genuinely mandatory principles; general rules that thoroughly guide the political and administrative discretion of the European Union, as well as the interpretative role of the jurisdictional community organ.

In other words, when article 13 requires that the Union and its Member States thoroughly bear in mind the welfare needs of animals as sentient beings, it means that the interpretation of the other Treaty provisions, and particularly article 114, must not only be compatible with this declaration, but must be in strict accordance with it, whereby in cases to the contrary, the interpretation would not be legitimate. Therefore in the public policies of the EU (especially those relating to internal commerce, investigation and transport), art. 13 entails no only a negative limit, but a positive parameter that must be borne in mind.

In this sense, its application in the Member States, particularly of the regulations on animal experimentation, has crossed certain vicissitudes that I will explain (specifically in the case of application in Spain) to critically examine the result of the transposition of Directive 2010/63/EU on the protection of animals used for scientific purposes. ${ }^{6}$

The transposition of this regulation in Spain was delayed and took three years and happened only after well-known resistances. Nowadays, regulation relating to animal experimentation is integrated by:

a) Royal Decree 53/2013, of 1 February $^{7}$, establishing basic standards for the protection of animals used in experiments and for other scientific purposes, including education;

\footnotetext{
(accessed October 2018)

${ }^{5}$ Treaty on European Union, of 7 February 1992, signed in Maastricht, DOUE n. 83, of 30 March 2010, pages 13 to 46 (34 pages) Ref. DOUE-Z-2010-70005. https://www.boe.es/buscar/doc.php?id=DOUEZ-2010-70005\#analisis (accessed October 2018).

${ }^{6}$ Directive 2003/65/EC of the European Parliament and of the Council of 22 July 2003 amending Council Directive 86/609/EEC on the approximation of laws, regulations and administrative provisions of the Member States regarding the protection of animals used for experimental and other scientific purposes, https://eur-lex.europa.eu/legal-content/EN/TXT/?uri=celex:32010L0063 (accessed October 2018)

${ }^{7}$ Royal Decree 53/2013, of 1 February, http://www.boe.es/boe/dias/2013/02/08/pdfs/BOE- ${ }^{\circ}$ C-A- ${ }^{\circ}$ C2013-으-1337.pdf
} 
b) Law 32/2007, of 7 November, ${ }^{8}$ for the care of animals, in their exploitation, transportation, experimentation and slaughter, and

c) Law 6/2013, of 11 June, ${ }^{9}$ which serves to, in addition to setting out the sanctioning procedure, facilitate the transposition of a part of Directive 2010/63/EU of the European Parliament and of the Council, of 22 September 2010 , on the protection of animals used for scientific purposes, through the modification of Law 32/2007.

One of the aspects that it is most interesting to point out here is the widening of the ambit of application of Law 32/2007 to incorporate invertebrate animals (such as cephalopods) and to the foetuses of mammals, within the category of sentient beings, the application of the regime of sanctions and infractions set by law.

The most relevant aspects of this regulation are the monitoring of the proceeding European legislation to extend this protection to animals used for experimentation on the premise that they are sentient beings, to set some compulsory limits, such as the principle of the three Rs (RD.53/2013, art.1.a), the movement towards ending experimentation with animals and their substitution with alternative methods, as well as subjecting experimentation to authorisation provisions by ethics committees.

The Royal Decree 53/2013, states restrictively in art.2) that "a)... the number of experiments is to be reduced to the minimum, applying alternative methods where possible; b) they [animals] should not be caused unnecessary pain, suffering, distress or lasting harm". Here it is worth considering the limits of the expression "unjustifiably", which still remains in art. 337 of the Criminal Code in reference to animal abuse, and the limits of the expression "unnecessarily", when referring to pain, suffering, distress or lasting harm that habitually accompanies experiments carried out on animals. This ambiguity on the limits to causing "unnecessary pain" to experimentation animals is consistent element in all regulations, which contrasts with an expression that is found later on (RD.53/2013, art.3.d), and limits the pain, suffering, distress and lasting harm (this set of terms is constantly repeated) equivalent to introduction of a needle, in accordance with good veterinary practices; ${ }^{10}$ if such a limit were, after all, to be applied, it would be both surprising and encouraging.

The principle of the three Rs (replacement, reduction, refinement), was formulated in the 50s by a group of scientists, whose collaboration resulted in a publication by Russell and Burch ${ }^{11}$ that, despite having since been reviewed and improved, can be considered the starting point for the consideration of sentience as the fundamental inspiration for legislation relating to experimentation animals. Scientists from all areas of science have stood in agreement on this matter in succeeding formal declarations, such as the Helsinki Declaration, which refers particularly to the ethics of biomedical experimentation, ${ }^{\mathbf{1 2}}$ and the

\footnotetext{
${ }^{8}$ Law 32/2007, of 7 November, https://www.boe.es/buscar/act.php?id=BOE-A-2007-19321

${ }^{9}$ Law 6/2013, of 11 June, https://www.boe.es/diario_boe/txt.php?id=BOE-A-2013-6271

${ }^{10} \mathrm{RD}$. 53/2013, art. 3.f: Procedimiento: La utilización, tanto invasiva como no invasiva, de un animal con fines experimentales u otros fines científicos, cuyos resultados sean predecibles o impredecibles, o con fines educativos siempre que dicha utilización pueda causarle al animal un nivel de dolor, sufrimiento, angustia o daño duradero equivalente o superior al causado por la introducción de una aguja conforme a las buenas prácticas veterinarias. [Procedure: Any use, invasive or non-invasive, of an animal for experimental or other scientific purposes, with known or unknown outcome, or educational purposes, which may cause the animal a level of pain, suffering, distress or lasting harm equivalent to, or higher than, that caused by the introduction of a needle in accordance with good veterinary practice]

${ }^{11}$ RUSSELL, W.M.S. and BURCH, R.L., The Principles of Humane Experimental Technique (London 1959).

${ }^{12}$ Helsinki Declaration, submitted by the World Medical Association in 1964, has been successively modified and widened, which also concerns biomedical investigation with animals; World Medical
} 
Basil Declaration, ${ }^{\mathbf{1 3}}$ the commitments of which have been increasingly adapted to the demands of scientific advancement in terms of the sentience of species other than mammals and, and regarding the need for transparency in the methods and results achieved by experimentation.

On the themes of transparency and the communication of results, the new legislation has ordered the creation of Ethics Committees charged with informing and authorising animal investigation protocols that must be presented in both public and private investigation centres, the regular evaluation and compulsory publication of investigation results, and also, perhaps the most important for the deconstruction of experiments, tending to reduce to nothing, in accordance with the spirit of the regulation, the obligation of training of those working in any stages of animal experimentation, and especially of those who start the investigation.

\section{VETERINARIANS AND JURISTS: A COMMON ASPIRATION}

By way of conclusive reflection, I will formulate some prospective solutions, about the role that corresponds to us, those who, as of our profession, assume the responsibility of particular vigilance over animals and the regulations that can guarantee a greater protection of their interests. These considerations can be summarily set out by the following points:

1. Veterinarians and jurists must work together for the welfare of animals. Each one of us provides a combination of varying abilities and knowledge regarding the adequate level of protection and care that animals must be afforded.

2. A legal discussion on animal welfare is different to a discussion based on science.

- In science, the discussion deals with how to describe and understand the optimal conditions for animal welfare. Science is also necessary for describing the consequences of the various living conditions on animals, if animals are provided with conditions below the welfare level required for their specie.

- The legal discussions on animal welfare are not about the optimal living conditions with which we provide them, but on the conditions that are so deficient as to amount to a punishable act (fines and prison sentences), or a violation of civil or administrative regulation (fines and the revocation of licences), for keeping animals in conditions below the established standards.

There generally exists a considerable difference between the best living conditions, and those that may be criminally punishable, in line with animal welfare. It is therefore advisable to distinguish between general prohibitions against cruelty - those which protect all animals - and the responsibilities of owners regarding animals within their proprietorship. In other words, the obligation to criminally defend animals from mistreatment, as with any vulnerable being, constitutes an obligation corresponding to each State, while the obligation to carry out good treatment toward animals, is a consequence of the responsibility that comes with proprietorship between humans and animals.

While science is centred around the animal, the creation of Law brings into play the balance of many differing and diverse factors. Law is, to a large extent, the result of a political process and the exercise of power, whose exercise is attributed to many diverse

Association Declaration of Helsinki: ethical principles for medical research involving human subjects, DOI: $10.1001 /$ jama.2013.281053

${ }^{13}$ Basel Declaration, https://www.basel-declaration.org/ 
actors and voices. Some will argue over the economic consequences, and others over the emotional consequences, some human beings make financial or political contributions so as to be heard more clearly, and others will form public groups of voters to argue in favour of certain legal positions, and initiatives take on many forms. In other words, the political process cannot ignore the values of society, which are changeable, for example, the protection of endangered species, the welfare of animals, the control of water pollution or child labour. The socially acceptable levels of animal welfare, just like the question of the contamination levels of the water, for example, are, in the end, political questions customisable for each country, and the differences that can be seen in the world around us suggest that the political responses are not, not could they be, the same in each country.

The generation of Law and of laws is the art of achieving a compromise between opposing views, within the political arena of a given State. For example, in the realm of the production animal, whether the criminal threshold for the breeding of laying hens is ten birds per battery cage, or perhaps three, or whether the cage should be illegal. Science can be of significant help in these types of considerations and debates, as it can provide verified and corroborated information on the aforementioned consequences for animal welfare so as to define the various alternatives to regulation that could be presented to the politicians responsible.

The legal debate on public policies is, instead, about what is socially unacceptable. In areas such as the welfare of production animals, or of animals in public shows, the role of Animal Welfare Science experts is, and has been, decisive, and today is out of the question, seemingly a responsibility recognised by the same professional collectives involved. But if the question is on the conditions that are acceptable for experimentation animals, then the role of veterinarians is even more important, due to the conditions, including the nature of the possible suffering, which is not as obvious for the public or for politicians. There is a genuine need for corroborated and reliable scientific information, for it is of the utmost importance for outlining an adequately solid and reliable legal plan that will effectively protect animals used in experiments.

There still remains a lot for us to know in terms of what nonhuman animals want and need from us, on the workings of the most complicated aspects of their organisms and of their sentience, and also on how we must treat animals of each specie. Animal welfare science must continue to carry out an important role in determining how we achieve our ethical and moral responsibilities, and how we legally regulate the lives of the animals with which we interact, with a basis in a practical and normative recognition of sentience.

\section{SOME REFERENCES}

- BAQUERO RIVEROS, J., La libertad para "Chucho", el oso andino de anteojos. Comentario a la Sentencia de la Corte Suprema de Justicia, Sala de Casación Civil, del veintiséis (26) de julio de dos mil diecisiete (2017), dA. Derecho Animal (Forum of Animal Law Studies) 9/1 (2018) https://doi.org/10.5565/rev/da.244

- BROOM, D.M., Sentience and Animal Welfare (Cambridge 2014)

- BROOM, D.M., Considering animals' feelings: Précis of Sentience and Animal Welfare, Animal Sentience, 5 (2016)

- CORREIA MENDONÇA, H., Recognising Sentience in the Portuguese Civil Code, dA. Derecho Animal (Forum of Animal Law Studies), 8/2 (2017) https://doi.org/10.5565/rev/da.12

- FERRER, Ll., Of Mice and Men: Reflexiones sobre la ética de la experimentación animal, dA. Derecho Animal (Forum of Animal Law Studies), 1/1(2010) https://doi.org/10.5565/rev/da.217

- GIMÉNEZ-CANDELA, M., La aguja y la pica, dA. Derecho Animal (Forum of Animal Law Studies) 3/4 (2012) https://doi.org/10.5565/rev/da.292 
- GIMÉNEZ-CANDELA, M., Cosmética y experimentación en animales, dA. Derecho Animal (Forum of Animal Law Studies) 4/1 (2013) https://doi.org/10.5565/rev/da.289

- GIMÉNEZ-CANDELA, M., Seres sintientes, dA. Derecho Animal (Forum of Animal Law Studies) 5/2 (2014) https://doi.org/10.5565/rev/da.277

- GIMÉNEZ-CANDELA, M., Los cocodrilos también lloran, dA. Derecho Animal (Forum of Animal Law Studies) 5/2 (2014) https://doi.org/10.5565/rev/da.277

- GIMÉNEZ-CANDELA, M., Animales y Derecho en una sociedad global, dA. Derecho Animal (Forum of Animal Law Studies) 5/3 (2014) https://doi.org/10.5565/rev/da.275

- GIMÉNEZ-CANDELA, M., La Descosificación de los Animales (I), dA. Derecho Animal (Forum of Animal Law Studies) 8/2 (2017) https://doi.org/10.5565/rev/da.318

- GIMÉNEZ-CANDELA, M., La Descosificación de los Animales (II), dA. Derecho Animal (Forum of Animal Law Studies) 8/3 (2017) https://doi.org/10.5565/rev/da.250

- GIMÉNEZ-CANDELA, M., Reforma del Cc. de Portugal: los animales como seres sintientes, dA. Derecho Animal (Forum of Animal Law Studies) 7/4 (2016) https://doi.org/10.5565/rev/da.255

- GIMÉNEZ-CANDELA, M., Es alguien (no algo), dA. Derecho Animal (Forum of Animal Law Studies) 9/1 (2018) https://doi.org/10.5565/rev/da.251

- GIMÉNEZ-CANDELA, M., Dignidad, Sentiencia, Personalidad: relación jurídica humano-animal, dA. Derecho Animal (Forum of Animal Law Studies) 9/2 (2018) https://doi.org/10.5565/rev/da.346

- GIMÉNEZ-CANDELA, M., La Descosificación de los Animales en el Código civil. español (Forum of Animal Law Studies) 9/3 (2018) https://doi.org/10.5565/rev/da.361

- GONZÁLEZ LACABEX, La ciencia también de su lado, dA. Derecho Animal (Forum of Animal Law Studies) 4/1 (2013) https://doi.org/10.5565/rev/da.151

- -HONJO, M., Recent Changes in Animal Testing Laws, dA. Derecho Animal (Forum of Animal Law Studies) 7/2 (2016) https://doi.org/10.5565/rev/da.44

- -LEYTON, Problemas Bioéticos de la experimentación con Animales no-Humanos, dA. Derecho Animal (Forum of Animal Law Studies) 1/3 (2010) https://doi.org/10.5565/rev/da.203

- MIRAS LARA, E., Experimentación animal, Real Decreto 53/2013, dA. Derecho Animal (Forum of Animal Law Studies) 6/1 (2015) https://doi.org/10.5565/rev/da.78

- MULÀ, A., Experimentación con animales: Sentencia del Tribunal Superior de Justicia de Cataluña no 315, de 31 de marzo de 2006, dA. Derecho Animal (Forum of Animal Law Studies) 4/1 (2013) https://doi.org/10.5565/rev/da.170

- PUMAROLA I BATLle, M., Animales e Investigación en Neuropatología Veterinaria, dA. Derecho Animal (Forum of Animal Law Studies) 4/1 (2013) https://doi.org/10.5565/rev/da.150

- RESCIGNO, F., Il Diritto dei Cosmetici. Regolazione, Responsabilità, Bioètica, dA. Derecho Animal (Forum of Animal Law Studies)5/1 (2015) https://doi.org/10.5565/rev/da.111

- ROWLANDS, M., Mentality and Animal Welfare (Commentary on Broom on Animal Welfare), Animal Sentience, 5 (2016)

- RUSSELL, W.M.S. and BURCH, R.L., The Principles of Humane Experimental Technique (London 1959)

- SAID CASTAGNO, K., Los animales como seres sintientes en la Constitución política de la Ciudad de México, dA. Derecho Animal (Forum of Animal Law Studies) 8/1 (2017) https://doi.org/10.5565/rev/da.18

- STEFFEN, J.L. - KLANOVICZ DE ARAÚJO, C., Animal Ethics: The current Debate, dA. Derecho Animal (Forum of Animal Law Studies) 6/3 (2015) https://doi.org/10.5565/rev/da.70

- VERGARA, PATRI, Nueva legislación sobre la protección de los animales utilizados en investigación, dA. Derecho Animal (Forum of Animal Law Studies) 4/1 (2013) 
https://doi.org/10.5565/rev/da.152

- VILlALBA,T., 40 años de Bienestar Animal: 1974-2014. Guia de la legislación comunitaria sobre bienestar animal (Madrid 2015)

- Foundation for Biomedical Research, https://fbresearch.org/ (acceso Octubre 2018) 